\title{
The Internet in French Language Teaching and Learning: Positive and Negative Impacts
}

\author{
Viviane Koua \\ Department of Languages, College of Liberal Arts, Auburn University, Auburn, Alabama, USA
}

\begin{abstract}
The computer assisted learning technology, like the internet, is considered an ideal aid for language teaching and learning. It provides a learner-centered and functional approach to knowledge but may present an easy but also a culturally limited, learning medium. Only a few studies examine the net benefits of the internet and other computer technologies on students' desire to learn a romance language in spite of the controversy surrounding their use in mastering a language. I examine the role of computer technology with emphasis on the internet and its associated media in the facilitation of teaching and learning French employing a review of literature, anecdotes from students' class interaction to point out that the computer enhancing technology, like the internet, is an important but controversial cultural and political tool for teaching and learning the French language.
\end{abstract}

Index Terms - computer, technologies, internet, French, teaching, learning

\section{INTRODUCTION}

Computer technology has become an important and indispensable tool in teaching and learning in recent years (Jensen 1993; Mike, 1996). Computer assisted learning language (CALL) programs, found on the internet, have been used profusely in science, mathematics engineering and the social sciences, but have been making gradual and unbalanced in-roads in the teaching of languages (Van Der Linden, 1993). Language teachers who have become attached to old fashion language laboratories have now recognized the benefits of the internet, (from here on is referred to as the 'Net'), and associated tools, and are using them as hybrids for combining the old style of drills and repetition with modern self-involvement. Technology has become an integral part of the learning process as new tools are being introduced and are made available to language teachers (Singhal, 1997). Many researchers and experts (Blake, 1987 and Chun and Brandl, 1992) have outlined numerous benefits of technology in language learning, and among them is the abundance of opportunities provided by this computer technology to learn the language. The opportunities provided, however, are not without costs. Many claim that while the computer may facilitate students' preparation for tests, and may increase students love for the language in the short-run; it may not enhance the long-term appreciation of the language and culture (Cononelos and Oliva, 1993). Others are of the opinion that learning and practicing grammar rules of foreign language through fill-in-the blank exercises, for example, does little to improve a speaker's ability to produce grammatically appropriate utterances (Armstrong \&Yetter-Vassot, 1994). The use of the Net, for example, for studying one language may not universally fit the teaching and learning styles of all languages. Warschauer and Meskill (2000) suggest that there is too much rigidity in CALL compared to language flexibility. Though Singhal, (1997) and Murphy (1995) state that computer assisted technologies enhance the teaching possibilities of French. In this paper, I examine the both sides of the discussion on the effects of computer assisted technologies on French teaching and learning.

The accusation of the computer assisted language learning technology increasing rigidities in teaching and learning French is not based on tests, but insinuations that are embedded in the attachment to older teaching habits, in that the teacher is the focus in the classroom experience and is unwilling to embrace new developments and change. Chapelle (2001) believes that the limitations in the use of the computer technology in teaching a foreign language are more influenced by the limitations of the software and the learner since the computer is merely a technological instrument. Romance language teachers, like those teaching French and Spanish, who are more adverse to change than science and technology teachers, require some cultural understanding and appreciation that the Net affords to language learning (Cononelos and Oliva, 1993). Hence many wonder whether such cultural enrichment is possible without human interaction and contact in the learning process. In this paper, I discuss the benefits of computer assisted language learning; the computer and French language accessibility; the computer and French language accuracy; the limitations of the Net and associated electronic and then I conclude.

\section{Benefits OF COMPUTER Assisted LANGUAGe LEARNING}

If we accept that cognitive approaches to language teaching are based on the view that learning is an individual process (Warschauer and Meskill 2000) then the individual computer can facilitate knowledge acquisition since the learner can work on language skills at any time. Educators (Jonassen, 1996; Rost, 2002) indicate that the computer and its attached language learning programs can provide second language learners more independence from classrooms; 
thus allowing them the option to work on their learning material at any time of the day and facilitate learning at their own pace. The benefits to be gained from learning do outweigh the costs. Lee (2000) listed a number of advantages of computer assisted language learning: (a) provide practices for students through the experiential learning, (b) enhance students learning motivation, (c) improve student achievement, (d) increase availability of authentic materials for study, (e) encourage greater interaction between teachers and students and peers, (f) emphasize the individual needs, (g) regard independence from a single source of information, and $(\mathrm{h})$ enlarge global understanding.

Computer technologies made accessible on the internet, do not only influence the learning process, but also enable the individual development, attitude and behavior. Chenu et al. (2007) in their study, however, found no correlation between positive attitude and successful outcomes. Taylor (1980) stated that computer assisted learning can stimulate interest in a language and provide communicative activities that reduce learning pressure while providing necessary growth in the language learning process. Itma (2010) argues that there is a possibility of improving the learning environment by using the Net as a tool to develop new learning styles and innovative methods of teaching French. The author stated that successfully teaching French within a degree program relies on methods that promote global reading, critical thinking, collaborative learning, reflection in the target language, and engaging students in the learning process by using information technology. Some of the Net based computer assisted learning activities include games, skits, and contests. Through communicative and interactive computer programs, learners' skills and attitude are modified and the learners develop confidence to study the language. Robertson et al. (1987) recognized that computer-assisted learning programs had significantly higher self-esteem ratings. Students who are shy and unwilling to speak out in class find it easy to participate in language conversation once they begin developing mastery of the language (Beauvois, 1995; González-Bueno, 1998; Warschauer, 1995). Beauvois (1997) reported that computer-mediated communication increased total class participation to $100 \%$.

In the study by Tuernbull and Lawrence (2001) $90 \%$ of the 274 teachers reporting revealed that computer application promoted French curriculum enhancement, improved appearance of students' work, provided remedial support for student work and variety in lesson planning, and helped in technology skill development. The authors also agreed that the computer assisted in motivational development.

Among the various electronic tools for learning languages, the Net it is argued, provides a vast amount of resources to students that would not be available to them in one geographical area. It enables learners to connect with people of different cultures and develop an appreciation of their cultures and customs that enable them to place language learning in a context. The Net may assist students in developing communicative skills and critical thinking. Morrison and Dede (2004) argue that the Net is an intelligent tool that facilitates learning and flexibility. Mike (1996) also believes that the Net has been shown to promote higher order thinking skills. Though the Net has been accused of using much instruction time, a language teacher, for example, may train learners to search for specific information which they would not have been able to find using books in the allotted time required to complete the exercise. Perrett (1995) mentioned that students are provided with the opportunities to use language at their leisure and learning strategies in the second language, and some training or explanation in their application through the Net.

The socio-cognitive approaches, in comparison to the cognitive, emphasize the social aspect of language acquisition (Warschauer and Meskill 2000). The Net, through its large coverage and abundance of information, places language learning in a socio-cultural context (Patrikis, 1995). According to Schieffelin \& Ochs (1986) and Gee (1996) learning a language can be viewed as a process of apprenticeship or socialization into particular groups, and students must be given the opportunity for social engagement where they are culturally immersed. It is believed that language and culture are highly dependent. The understanding of the culture enhances the learning process and facilitates the development of an appreciation for the language (Trivedi, 1978). In this light, the Net is important to teachers and students who would like to learn about the people who communicate in the language. As Warschauer and Meskill (2000) stated, students in advanced business French class at Case Western Reserve University in Ohio can Follow French news online and get involve in daily happenings in France. Scinncariello (1995) indicated this helps the students learn background cultural information about current events and attitudes in France, as well as noting the various forms of discussion. The Net improves learning about the countries of the world where the language is spoken and provides the learners' access to historical and current information as well as geographical, historical, social/cultural, economic, and political information from the countries in which the target language is spoken (Armstrong and Yetter-Vassot, 1994). Students can read web versions of daily newspapers and same-day news. Students with various tastes for sports, culture, fashion and poetry can access reports from sources such as the French Embassy's gopher service, and the daily ''Revue de Press". Such experiences can allow learners to participate in the culture of a targeted language which in turn can enable them to further learn how cultural background influences one's view of the world. Teachers can effectively use this medium to encourage students to obtain newspaper clippings and summarize them. This helps the students to relate what they learn in the textbook to current events (Can, 2009).

The e-mail is another internet based computer tool that facilitates teaching and learning of a language. It facilitates teacher/student communication. Gonglewski et al. (2001) stated that the e-mail, a computer-mediated communication, has been called "the mother of all Internet applications". They listed a number of advantages of the e-mail. The e-mail allows learners to make contributions to the learning process (Rankin 1997). The teacher is able to communicate with all students in the class in various locales simultaneously and in a nano-second and this ensures that the same message 
is conveyed undiluted to all participants (Jonassen, 1996). With the e-mail students can make contributions to the learning process at any time. This provides reliability and consistency in communication. The e-mail can reduce personal contact allowing one teacher to spend more time with students who actually need more attention (Kroonenberg, 1994/95). It is also a fascinating tool to use for long distance learning for teaching a language since it extends what one does in the classroom because it provides a venue for meeting and communicating in the foreign language outside of class (Davis et al. 1994/1995). Students and teachers can communicate with others around the world (Hedderich, 1997; Roakes, 1998). By sending e-mail and connecting to various people globally, one has never known, the learners can expand their horizon and accelerate the learning process. As Signhal (1997) stated the e-mail allows language learners to communicate directly with native speakers; thus the net facilitates the use of the specific language in an authentic setting. With the use of the e-mail, individuals can make sense of abstract materials through social interaction on the Net. Schwienkorst (1998) suggested that the e-mail can help in the improvement of written communication.

Computer assisted language learning (CALL) programs accessible through the Net have been presented as technologies that may revolutionize the teaching and learning of languages (Blin, 2005). There are numerous software packages introduced in the classroom which speeds up the learning process of languages. There are a number of applications available for learning and teaching vocabulary, grammar, and pronunciation tutors, spell checkers, electronic workbooks, writing and reading programs (Paramskas, 1993). There are also a new software packages that allow instructors to create their own exercises to supplement existing language courses. These packages have been criticized for presenting limited exercises and modules for stimulating interest in the language (Villada, 2009). However, there have been numerous new learning tools on the market. There are other interactive programs that provide immediate feedback to students while learning the language. The learning software packages are becoming more userfriendly and allow the students to practice at their own speed (Kulik and Kulik, 1991). Though the growth of the software learning curve has not received much attention, I believe that once the students obtain the hang of it the learning process accelerates. One of the most popularly used Net packages, but much criticized, is the translation software. The French translation software is criticized for encouraging dependence on a technology which is not culturally and politically sensitive (Eisner, 1976). The Net and French translation will be dealt with in another section.

\section{French COMPuter TeChNOlOGy ACCESSibility AND USAGE}

The use of computer technology is here to stay and its use in teaching French will proliferate with time and by countries. Already in Canada it is used in more than 50 percent of schools (Turnbull and Lawrence, 2001). The net is one of the principal cyber communication outfits in use today. It has also been one of the primary technology integration tools used to stimulate the learning of foreign language. English has really dominated the net, but the Net can be a powerful instrument for learning French (Williamson, 1998). French, however, still has a relatively small presence on the Website and the French has made little effort until recently to advance in the digitalization of its literature and culture (Lupien, 2005). It is estimated that about 750 million people globally use the net annually. The largest number of English speakers amount to 59.8 million or 26.8 percent of total users. This is followed by Chinese which makes up about 24.2 percent. Only about 59.0 million people or 3.0 percent of French users access the Net. Though this might provide a basis for interpretation of the Net use, because of population differences, the penetration of the net by French users is $17.2 \%$ in comparison to 79.5 percent for Germany and $78.4 \%$ for Japan. Internet penetration is the ratio between the sum of internet users speaking a language and the total population estimate that speaks the language. What is most striking is the growth of the various language users which is 2,501.2 percent, 1, 825 and 1,478.7 percent for Arabic, Russian and Chinese respectively, but only 301.4 percent for French from 200 to 2011.

The limited access of French users to the Net means not only a small percentage of French speakers use the internet but the penetration and growth are slow compared to other countries (Neisen on Line (2001). It also translates into a lack of French information and materials available for teaching and social interaction on the Net. Therefore, students learning and studying French globally may have a disadvantage in their ability to access information and to participate in cultural engagement with French speakers and other students.

The accessibility of learners of French to computers may vary by country since a study by Turnbull and Lawrence (2001) in which 274 out of 500 Canadian teachers had responded showed that $58 \%$ of teachers surveyed showed that they used computers in core French courses while $61 \%$ had used computers for laboratory exercises. About $60 \%$ showed a preference for using computers in both classrooms and laboratories. A large percentage (41\%) had never used computers. About $87 \%$ of 88 students had computers at their homes.

In the same study by Turnbull and Lawrence (2001) students reported learning more French when computers are part of their lesson plan. About $96 \%$ indicated that computers helped them with their lessons, their reading skills, and more about French culture. About $92 \%$ felt that computers helped them write better and the same percentage felt that computers helped them learn independently. While students may claim that computer assisted instruction helped them to learn better, Chenu et al (2007) did not find much difference, but indicated that individuals with low level French learning aptitude benefited the most from CALL. In a study by Adair-Hauck et al. (1999) they found that students using technology-Enhanced Language Learning, Multimedia curriculum performed equally well as those learning French using the traditional method in listening and speaking and better on reading and writing achievement measures. 


\section{The COMPUTER AND French LANGUAGE ACCURACY}

French is a Romance language that is spoken with passion and accuracy. The quality and accuracy of the French language grammar have been guarded politically. However, there is much suspicion that the wider use of computers in teaching and learning French is based on the whole ecology within which the computer technology is viewed. While political might is being displayed to maintain a pure language that represent cultural superiority, the French seemed to be retarding the important introduction of a technology which may irrevocably change the language for fear that the technology might adulterate the accuracy of the language with the introduction of new words and slang into the language. Hence we may say they are 'throwing the baby out with the bath water'. This is myopic approach of guarding the accuracy of language by carefully scrutinizing the rapid adoption of new words and phrases into the language while limiting the diffusion of a technology that may enhance its cultural embrace by non-native speakers for fear of the loss of accuracy and cultural subjugation.

The government of France has introduced legal and cultural barriers to preserve the paccuracy and integrity of the French language because it is believed that the French language, and consequently the French nation are under attack of cultural imperialism (Grigg, 1997; Cohen 2012). The Loi Toubon was passed in 1994 and states that any government entity, broadcast media and advertising companies that use foreign words where suitable "French equivalents" exist will be fined $\$ 2,000$ for the first offence and up to $\$ 4,000$ for the second offense and sentenced to prison terms (Yentz 2007, Scheel, 1998). The linguistic accuracy of the French language has been protected by the prevention of infiltration of other languages and cultural expressions through songs and music into the language. The French cultural ministry regulates the percentage of French songs that can be played on the radio (Yentz, 2007). However, with the influence of cultural penetration, global commerce and migration there has been a perceived decline in the accuracy of the French language (Scheel, 1998). This perceived dwindling in accuracy has been accelerated with the Net, and other technologically advanced instruments of communication.

There are other areas, sports, technology, advertising, and the media, where the English influence is heavily felt. The introduction and use of new technology in the common French language are accelerated by the adoption of musical lyrics and the audiovisual system. In 1996 for instance only $48 \%$ of the songs played on the radio had French origins (Gordon and Meunir, 2001). This has serious financial and economic implications. According to Cohen (2012) in 1998 the market for American audiovisual goods in European Union, "including movie ticket sales, videocassette rentals, and television rights," was $\$ 7.4$ billion, compared to reverse US market for the same European goods, totaling \$706 million (Gordon and Meunir, 2001).

The Cyber Challenge is even greater when it comes to the internet because the French has no way of controlling the use of the net. According to Cohen the internet challenges the French agenda to keep out English words and promote the use of French. First English overwhelmingly dominates the internet; in 2012 reports show that only 4.1\%of websites had French content, lagging behind English with $56.1 \%$. The second aspect is that the internet does not lend itself to policing as the Minitel; hence individuals are free to roam and contact individuals from any other country or cite.

The internet has added a number of new words to the French language. Some words have crossed over directly from English in spite of the dismay of the French purists. Terms such as 'l'internet, le web, and le cyberspace' are only a few (Williamson, 1998). It is feared that a number of words found on the Net are English words in which the individuals add a 'le' in front of the word instead of doing the proper translation. Some of those words "le week-end", "le parking", "le jogging", "le footing" show the inclusion of English words into the French language. The permeation of such words into the French language, it is claimed, will introduce a new culture into the language since students believe it is cool to speak English (Scheel, 1998). It is believed that if this process continues students who use the Net for learning will develop a sub-culture where they will disregard French grammar rules and just add a 'le' in front of a new English word when translation becomes difficult. Culture is related to language and with time new words will be added to a language, and that is what excites young learners of a language.

One major criticism in prolonging the purity of the language at the College level is related to translation from English to French. At the college level, students often use Net downloaded software for translation. The software translation may alter the purity and style of the French language as students seek quick ways of learning the language. The quality and structure of the text may be invariant to the correct speaking and use of the language. There are many ambiguous words that may not translate the correct meaning of the language. There are words like "apporter" (bring something) and "amener" (bring someone); "à ma maison" (at home) instead of "chez moi"; "Je te manque beaucoup" (I miss you a lot) instead of "Tu me manques beaucoup"; "si je suis bonne impression" (if I'm in good mood ) instead of "si je suis de bon humeur"; "Alors" (then) instead of "Ensuite"; "J'ai dit à lui" (I told him) instead of "je lui ai dit"; "J'ai pris un voyage" ( I took a trip) instead of "j'ai fait un voyage"; "J'ai fait mon breakfast" (I made my breakfast) instead of "J'ai fait mon petit dejeuner"; "je me mange" (I eat myself) instead of "je mange" (I eat). The words if used inappropriately can make quite a difference. There are other words that may have more than one meaning and if not translated properly may cause social uneasiness. The word "coucher avec"( to sleep with someone) instead of "se coucher"(to lie down) may result in social disgrace if translated improperly as it almost cost isolation of one pop singer from her religious community and father.

With the use of the Net, individuals often try to communicate by using phonetics instead of proper spelling and grammar. Others use slang and write coded words and phrases to prevent individuals outside the loop from 
understanding. An example of this is "verlang" which is used to promote secret forms of communication among groups. There do not seem to be any proper rules in the design and use of slang. Hence this generates the debate and constrains the furtherance and modernization of the French language and the adoption and inclusion of new terms that the younger generation uses. However, there has been no research conducted as to whether the inclusion of new terms and phrases in a language facilitates the learning process.

In order to combat the introduction of words into French and the influence of the new cyber technology, the French Minister for Culture suggested diffusion of the French language and culture through the net instead of working against it. In his speech he emphasized removing any technological obstacles which may impede the presence and successful diffusion of the French language (Tattersall, 2003). The Académie Francaise is more worried to introduce words to meet the equivalents of English equivalents, for example "logicel for software; matériel for hardware, ordinateur for computer and baladeur for Walkman (Grigg 1997).

\section{Limitations of USE OF THE Net AND Associated EleCtronic LEARNing PACKages}

The Net has been hailed as an ideal tool to facilitate learning as it allows the student to be the focus of learning and encourages education planners to seek ways of enhancing students' participation in the learning process. The Net serves as a learning tool but is not a panacea for language teaching and learning. Gips, DiMattia, \& Gips (2004) indicated that the computer and its attached language learning programs increase cost for some students who are unable to purchase the computers and can ill-afford the monthly charges of the Net. The Net is said to create disparity in knowledge access and learning. While this may be true in the short run the costs of computers have been at a decline and people are able to access the Net at a low cost through various telephone devices (Guo et al., 2007; Lai and Kritsonis, 2006). What must be understood is that more people are able to access the e-mail for instance than people are able to globally gain access to a college education. Hence the internet may be used as a means of teaching a language to larger amounts of students at college level without them stepping foot into a college classroom.

Another criticism is that not all teachers have the training and skills to teach language using the computer (Turnbull and Lawrence, 2001). Though this problem persists in some locales the setback is being tackled by some institutions by providing some training to teachers on the use of the computer for teaching languages (Rost, 2002). As this problem is recognized by institutions of higher learning they may put in place incentives to encourage more teachers to embrace the technology. This problem may soon vanish as a new generation of computer savvy teachers replace the older generation of teachers (Kreutzer and Neunzig, 1997).

Computer assisted learning tools are criticized for being restricted to the learning of grammar, and loaded with drills and exercises geared towards preparation of students to succeed in multiple choice exams. This view is not supported by Murphy (1995) who believes that the Net is the ideal tool to access resources, exchange ideas, ask questions and most importantly, to give students access to the new global classroom. The speaking programs, it is also argued, do not allow students to practice and immerse themselves in the cultural aspects of the language. As Ariew (1984) puts it "The computer is just not capable of interacting orally with anyone at this time". He indicated that some activities may be orally cued, and hence exchange cannot take place. The language exercises found on the Net may not present accurate French text that is culturally correct and acceptable to French purists. Warschauer (2004) pointed out that a program should ideally be able to understand a user's "spoken" input and evaluate it not just for correctness but also for "appropriateness".

Students of a language are often faced with different situations, and learning problems. It is believed that the computer learning packages are unable to handle changing situations and circumstances (Aoki, 1984). The language packages are unable to think and deal with changes. Dent (2001) stated that the problem exists because humans and computers utilize information differently. Blin (2004) inferred that the computer technology does not operate with the degree of intelligence that allows it to change methods of processing to interact sufficiently with various users.

The old time adherents to the forms of learning where students must be subjected to long periods of contact with their teachers are worried that the use of the computer discourages the speaking of the language (Lee, 2000). Though it is agreed that the computer can be used to practice grammar, fill-in-the -blank exercises do not help to improve a speaker's ability to produce grammatically appropriate sentences (Amstrong \& Yetter-Vassot, 1994). The rigidity and complexity of learning a language are lost by using programs that provide only drills for learning the language (Jung, 2003).

\section{CONCLUSIONS AND IMPLICATIONS}

The computer provides immense potential for teaching a foreign language and increasing students' willingness to study the Romance Languages, especially French. It is stated that the computer provides them with an abundance of information in one place and in a very short time. However, French speakers are less likely to access the Net than other major language speakers; thus providing students of French less information sources and chances for cultural engagement. Hence college students from countries who adopt French as a second language may not easily connect on the Net with counterparts who speak French as their primary language for social and cultural exchanges. The students learning behavior, attitude and interests can thus only be altered to a limited extent as they interact with their 
counterparts globally. Their ability to develop deep interests is constrained as they attempt to make cultural inroads as they examine native speakers use the language. However, there are other negatives associated with the study of the language as the rigidity, correctness; thoroughness and appropriateness usually suffer with the use of cyber technology. The benefits of the use of the Net for teaching French seem to outweigh the costs, but teachers must be careful to stress the accuracy required to maintain language accuracy and the important linkages between the cultural setting and the spoken language. The purists of the French language, however, may not be convinced that the information received on the computer is reliable enough to enhance the proper learning and sustain the purity of the French language.

\section{REFERENCES}

[1] Adair-Hauck,B.; L. Willingham-McLain; B.E. Youngs, Evaluating the integration of technology and second language learning; CALICO Journal, vol. 17 (2):269-305.

[2] Amstrong, K.M. \& Yetter-Vassot, C. (1994). Transforming teaching through technology. Foreign Language Annals, 27 (4), 475-486.

[3] Aoki, P.K. (1984). Limitation of Current Microcomputers for foreign language training, Foreign language Annals, v.17 n 4 : 409-12.

[4] Armstrong, K.M. \& Yetter-Vassot, C. (1994). Transforming teaching through technology. Foreign Language Annals, 27(4), 475-486.

[5] Ariew, R. (1984). Computer-Assisted Foreign Language Materials: Advantages and Limitations, CALICO Journal, vol.2, No.11-5.

[6] Blake, R. (1987). CALL and the language lab of the future. ADFL Bulletin, 18(2), 25-29.

[7] Beauvois, M. H. (1995). E-Talk: Attitudes and Motivation in Computer-Assisted Classroom Discussion. Computers and the Humanities. 28, 177-190.

[8] Beauvois, M. H. (1997). Computer-Mediated Communication (CMC): Technology for Improving Speaking and Writing. In Michael D. Bush and Robert M. Terry (Eds.), Technology-Enhanced Language Learning. (pp. 165-184). Lincolnwood, IL: National Textbook Company.

[9] Blin, F. (2004). CALL and the development of learner autonomy: Towards an activity-theoretical perspective; Journal ReCALL vol 16(2):377395.

[10] Blin, F. (2005) CALL and the Development of Learner: An activity theoretical study; Thesis submitted fot the Doctoral of Philosophy in Education Technology; The Open University; pp 344.

[11] Can, T. (2009). Learning and teaching language online: A constructivist approach; Novitas-ROYAL; vol: 3 (1)60-74.

[12] Chapelle, C. A. (2001). Computer Applications in Second Language Acquisition: Foundations for teaching, testing and research, Cambridge University Press; http:// catdir.loc.gov/...

[13] Chenu, F. F. Garaud and W. Tong. (2007). Is computer assisted language learning (CALL) efficient for grammar learning? An experimental study in French as a second language; The JALT CALL Journal; Vol. 3(3): 85-93.

[14] Chun, D.M., \& Brandl, K.K. (1992). Beyond form-based drill and practice: Meaning- enhanced CALL on the Macintosh. Foreign Language Annals, 25(3), 255-267.

[15] Cohen, Laura"The French Identity Crisis: Fending Off the Franglais Invasion" (2012). Honors Projects. Paper 5. http://digitalcommons.iwu.edu/french_honproj/ Retrieve5/December, 2012.

[16] Cononelos, T. \& Oliva, M. (1993). Using computer networks to enhance foreign language/ culture education. Foreign Language Annals, 26(4), 527-534.

[17] Davis, B. \& Chang, Ye Ling. (1994/95). Long distance collaboration with on-line conferencing. TESOL Journal, 4(2), $28-31$.

[18] Dent, C. (2001). Studer: classification v. categorization. Retrieved June 28, 2006, from http://www.burningchrome.com:8000/ cdent/fiaarts/docs/1005018884:23962.html.

[19] Eisner, E. (1976). Educational connoisseurship and criticism: Their form and functions in educational evaluation. Journal of Aesthetic Education, 10, 135-150.

[20] Gee, J.P. (1996). Social linguistics and literacies, London; Talor and Francis.

[21] Gips, A., DiMattia, P., \& Gips, J. (2004). The effect of assistive technology on educational costs: Two case studies. In K. Miesenberger, J. Klaus, W. Zagler, D. Burger (eds.), Computers Helping People with Special Needs, Springer, 2004, pp. 206213.

[22] Gonglewski, M., Meloni, C., \& Brant, J. (2001).Using e-mail in foreign language teaching: Rationale and suggestions. The Internet TESL Journal, 7(3) Retrieved December 4th, from http://iteslj.org/Techniques/Meloni-Email.html

[23] Gonzalez-Bueno, M. (1998). The effects of electronic mail on Spanish L2 discourse; Language Learning and Technology; vol.1 (2):55-70.

[24] Gordon, P. H., and S. Meunier. (2001). The French challenge: Adapting to globalization, Washington, D. C.: Brookings Institution Press. Print.

[25] Grigg, P. (1997). Toubon Or Not Toubon: The influence of the English Language in Contemporary France. English Studies, 78.4:368. Pp. 368-384.

[26] Guo, S., M.H. Falaki, E.A. Oliver, S. Ur Rahman, A. Seth, M.A. Zaharia, and S. Keshav. (2007). ACM SIGCOMM Computer Communication Review; Volume 37, Number 5:95-100.

[27] Hedderich, N. (1997). Peer tutoring via electronic mail. Die Unterrichtspraxis/Teaching German, 2, 141-147.

[28] Itma, M. (2010). Effects of reading styles on using technology in a traditional learning environment when teaching a foreign language. Educause Quarterly (EQ) Vol. 33, no. 3. Retrieve December 4 from http://www.citeulike.org/user/sarspri/author/Itma:M

[29] Jensen, R. (1993). The technology of the future is already here. Academe, 8-13.

[30] Jonassen, D.H. (1996). Computers in the classroom. Englewood cliffs, NJ: Merrill. 
[31] Kreutzer, M., \& Neunzig, W. (1997). Computer assisted learning teacher training methodology and evaluation of a seminar for language teachers. CALICO Journal, 14, 65-79. Retrieved December 1, 2008, from https://calico.org/page.php?id=5.

[32] Jung, Hee-Jung. (2003). Overview of Computer Assisted Language Learning Research with Second Language Acquisition Perspectives,Teaching English with Technology, vol.3, no3, pp.3- http://www.iatefl.org.pl/call/callnl.htm

[33] Kroonenberg, N. (1994/95). Developing communicative and thinking skills via electronic mail. TESOL Journal, 4(2), $24-27$.

[34] Kulik, J., \& Kulik, C. (1991). Effectiveness of computer-based instruction: An updated analysis. Computers in Human Behavior, 7, 75-94.

[35] Lai, Cheng-Chieh and W. A. Kritsonis. (2006). Doctoral Forum, National Journal for Publishing and Mentoring Doctoral Student Research, Vol.3, No. 1.pp.6.

[36] Lee, K.W. (2000). English teachers' barriers to the use of computer assisted language learning, The Internet TESL Journal. Retrieved June, 25, 2006, from http://www.4english.cn/englishstudy/xz/thesis/barrir.

[37] Lupien, P. Le meilleur. (2005). (The Best) de l'internet: A Review of French-Language Information Sources, Recherche sur L internet Vol. No. 8-Sep.

[38] Mike, D. (1996). Internet in the schools: A literacy perspective. Journal of Adolescent and Adult Literacy, 40(1), 1-13.

[39] Morrison, J. L. and C. Dede. (2004). The future of learning technologies: An Interview with Chris Dede; Innovate; http://www.innovateonline.info/index.php?view=article\&id=1.

[40] Murphy, E. (1995), The French immersion teacher's guide to the internet; Journl of Immersion Teachers. Vol. 18(2) 37-40.

[41] Paramskas, D. (1993). Computer-assisted language learning: Increasingly integrated into an ever more electronic world. The Canadian Modern Language Review, 50(1), 124-138.

[42] Patrikis, P. (1995, winter). Where is computer technology taking us. ADFL Bulletin, 26, 2: 36-39.

[43] Perrett, G. (1995). August Communicative language teaching and second language acquisition theory. Paper delivered at 1993 MLTA Conference. Published in MLTAQ Inc. Newsletter No. 101.

[44] Rankin, W. (1997). Increasing the communicative competence of foreign language students through the FL chatroom. Foreign Language Annals 30(4), 542-546.

[45] Roakes, S. (1998). The Internet: A goldmine for foreign language resources. Retrieved from the World Wide Web on February 2, 2001, at http://www.call.gov/resource/essays/internet.htm.

[46] Robertson, E. B.; Ladewig, B. H.; Strickland, M. P., \& Boschung, M. D. (1987). Enhancement of self-esteem through the use of computer-assisted instruction. Journal of Educational Research, 80 (5), 314-316.

[47] Rost, M. (2002). New technologies in language education: Opportunities for professional growth. Retrieved June 28, 2006, from http://www.longman.com/ae/multimedia/pdf/MikeRost_PDF.pdf.

[48] Scheel, S. L. (1998). French Language Purism: French Linguistic Development and Current National Attitudes, A thesis presented to the Deapartment of Romance Languages and Honors College of the University of Oregon, Covalis, Oregon, $79 \mathrm{pg}$.

[49] Schieffelin, B.B., \& Ochs, E. (1986). Language socialization. Annual Review of Anthropology. 15:163-191.

[50] Schwienkorst, K. (1998). The "third place" - virtual reality applications for second language learning. ReCALL, 10(1), 118-126.

[51] Scinicariello, S. G. (1995). Le SMIC Jeune: Gathering information and language from foreign language newsgroups In M. Warschauer (Ed.) Virtual Connections: Online activities and projects for networking language learners. Honolulu, HI: University of Hawaii, Second Language Teaching and Curriculum Center.

[52] Singhal, M. (1997). The Internet and foreign language eduction:Benefits and challenges; The Internet TESL Journal, vol.III,No.6, June; http://www.gse.uci.edu/ed168/resume.html.

[53] Tattersall, Alex. (2003). The Internet and the French language. Centre for Language Education:Occasionla Paper N0.65. Southhampton: Southhampton University.Web.

[54] Taylor, R. (1980). The computer in the school: Tutor, tool, and tutee. New York: Teachers College Press.

[55] Trivedi, H. C. (1978). Culture in Language Learning; ELT Journal, XXXII(2):92-97.

[56] Turnbull, M. and G. Lawrence; Core French teachers and technology: Classroom application and belief systems; Final Report; CASLT2001.

[57] Van Der Linden,V. (1993). Does feedback enhance computer-assisted language learning? Computer Education; vol. 21, No.12:61-65.

[58] Villada, E. G. (2009). CALL evaluation for early foreign language learning: A review of the literature and a framework for evaluation. CALICO Journal. Vol. 26, No. 2:263-389.

[59] Warschauer, M. (1995). Comparing face-to-face and electronic discussion in the second language classroom. CALICO Journal, $13(2 \& 3), 7-26$.

[60] Warschauer, M. (2004). Technological change and the future of CALL. In S. Fotos \& C. Brown (Eds.), New Perspectives on CALL for Second and Foreign Language Classrooms (pp. 15-25). Mahwah, NJ: Lawrence Erlbaum Associates.

[61] Warschauer, M.and C. Meskill. (2000).Technologyand second language teaching; in Technology and second language learning. In J. Rosenthal (Ed.), Handbook of undergraduate second language education (pp. 303-318). Mahwah, New Jersey: Lawrence Erlbaum.

[62] Williamson, K. (1998). Discovered by chance: the role of incidental information acquisition in an ecological model of information use. Library and Information Science Research, 20(1), pp. 23-40.

[63] Yentz, A. (2007). The effects of France's language protection Laws on French media, IES Nantes, France. 


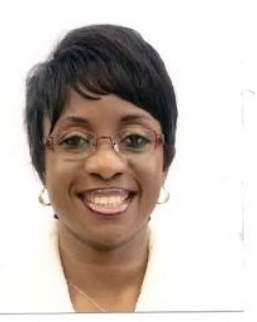

Viviane Koua was born in Cote d'Ivoire in December $21^{\text {st }}$, 1973. She received most of her early education in Abidjan. Côte d'Ivoire, West Africa.

Dr. Vivane Koua is a lecturer of French in the Department of Languages, College of Liberal Arts at Auburn University, Alabama. She received a first Master in Francophone Theater from University of Cocody, Abidjan, Ivory Coast, in 2000; then a second Master in French and Francophone Comparative Literature in 2001, a Ph.D. in French and Francophone Comparative Literatures from the University of Limoges, France, in 2006 and an MA in French and Applied Linguistic from Texas Tech University, USA, in May 2008.

She has conducted research in the areas of French teaching and learning styles, French and Francophone cinema, theater and cultures. Her current research interests are in the area of Francophone studies: the francophone literatures and cultures of Africa; French Afro-Caribbean literature and the literature of Maghreb. 